\title{
Modelowanie funkcjonalne stawu biodrowego z wykorzystaniem kapoplastyki
}

Streszczenie. $W$ artykule przedstawiono przedzabiegowa metode rekonstrukcji stawu biodrowego z rozpoznaną chzs z zastosowaniem DHRS. Metoda zasadza się na doborze i aplikacji endoprotezy powierzchniowej do obręczy miednicy odtworzonej na podstawie CT. Wirtualną aplikację poprzedzają pomiary struktur anatomicznych. Opracowana procedura pozwala na funkcjonalny dobór komponenty panewkowej i udowej do indywidualnych warunków pacjenta.

Abstract. This paper presents the preoperative hip reconstruction method with diagnosed OA using DHRS. The method is based on the selection and application of the resurfacing to the pelvis reconstructed on the basis of CT. The virtual application precedes the measurements of anatomical structures. The developed procedure allows for functional selection of the acetabular component and the femoral component to the individual conditions of the patient. (The functional modeling oh the hip joint using the resurfacing).

Słowa kluczowe: koksartroza, endoprotezoplastyka powierzchniowa, modelowanie, biometrologia Keywords: coxarthrosis, resurfacing, modeling, biometrology.

\section{Wstęp}

Zmiany zwyrodnieniowe w stawie biodrowym maja zróżnicowaną etiologię. Proces rozpoczyna się zmianami w chrząstce lub podchrzęstnej warstwie kości w wyniku zaburzeń metabolicznych lub nieprawidłowych procesów biomechanicznych (niestabilność stawu, nadmierne obciążenie, nieosiowość, uraz). W miarę postępu choroby zmiany się pogłębiają. Totalna alloplastyka i kapoplastyka stawu biodrowego są obecnie najczęściej stosowanymi metodami leczenia zaawansowanych zmian zwyrodnieniowych [1-4]. Nie można jednoznacznie powiedzieć czy protezoplastyka powierzchniowa jest lepsza niż klasyczne implanty [1,2,5-7]. Ograniczeniem kapoplastyki jest fakt, że komponenta udowa musi być osadzona na zdrowej, nie zmienionej osteoporotycznie kości udowej. Zaletą jest mniejsza ingerencja chirurgiczna, oraz większy zakres ruchu, ze względu na dużą średnicę komponenty udowej i panewkowej. Procedura zabiegowa powinna zapewnić prawidłowy dobór i fiksację elementów endoprotezy we właściwym przestrzennym ustawieniu oraz odtworzyć biomechanikę stawu. Niewielkie błędy osadzenia skutkują zwiększonym zużyciem i zmniejszona przeżywalnością implantu. Te przesłanki skłoniły autorów do opracowania metody, która przed zabiegiem kapoplastyki pozwala wykorzystać procedury diagnostyki obrazowej, modelowania oraz pomiary struktur anatomicznych do funkcjonalnego doboru konstrukcji protezy. Ponadto wirtualne odtworzenie struktur kostnych pasa biodrowego może być podstawą do jego replikacji z poliamidu na drukarce 3D. Na tej podstawie można ustalić krok po kroku procedurę zabiegową. W ten sposób wirtualne informacje mogą być przeniesione do sali zabiegowej i na obecnym etapie, w warunkach skomplikowanych zabiegów są wykorzystywane, aby usprawnić i skrócić czas operacji.

Celem jest opracowanie metody analizy biometrologicznej w zespole rekonstruowanego biodra $\mathrm{i}$ wirtualnej aplikacji endoprotezy powierzchniowej, dobranej i pozycjonowanej na podstawie badań morfometrycznych obręczy miednicy indywidualnego pacjenta.

\section{Materiał i metoda badań}

Materiałem do przedstawienia metody był przypadek kliniczny pacjenta (mężczyzna, I.62 z rozpoznaną choroba zwyrodnieniową lewego stawu biodrowego) ze wskazaniem zabiegu kapoplastyki. Przedzabiegową procedurę zmierzającą do wymiany powierzchni stawowych przedstawiono na odtworzonym przestrzennie, na podstawie CT, modelu numerycznym pasa biodrowego tego pacjenta.



Rys.1. Schemat procedur doboru i pozycjonowania endoprotezy powierzchniowej stawu biodrowego w strukturach anatomicznych pacjenta 
Usytuowanie komponenty panewkowej i komponenty udowej w strukturach kostnych decyduje o warunkach eksploatacji sztucznego stawu. Z uwagi na występowanie osobniczych różnic w układzie kostno-stawowym obręczy miednicy podstawowym zagadnieniem przed zabiegiem implantacji stawu biodrowego, staje się identyfikacja parametrów geometryczno-anatomicznych, które występują w układzie miednicy i kości udowej.

Kolejnym działaniem jest wybór konstrukcji endoprotezy powierzchniowej z bazy implantów dopuszczonych do aplikacji ortopedycznych uwzględniający wyznaczone parametry.

Wyselekcjonowane konstrukcje lub konstrukcja endoprotezy zostają zamodelowane w 3D. Końcowym efektem przeprowadzonych procedur jest dobór i celowana aplikacja biometrologiczna usytuowania implantu w kości miednicznej i kości udowej pacjenta, zgodnie z wyznaczonymi parametrami anatomiczno-geometrycznymi i uwarunkowaniami biomechanicznymi.

Etapy opracowanej metody przedstawiono na schemacie procedur doboru i pozycjonowania endoprotezy powierzchniowej w strukturach anatomicznych pacjenta (rys.1).

\section{Modelowanie i pomiary struktur kostnych}

Wirtualne odwzorowanie układu kostno-stawowego pasa biodrowego wytypowanego pacjenta zostało przeprowadzone w oparciu o obrazowanie w technice spiralnej wykonane w wysokiej rozdzielczości na 64rzędowym aparacie Siemens Somatom Sensation Cardiac w Pracownie Diagnostyki Obrazowej Szpitala Jana Pawła II w Krakowie dla najmniejszej z możliwych szerokości skanów równej $0,4 \mathrm{~mm}$ oraz największej możliwej rozdzielczości w każdym Skanie(1 woksel - 0,4mm x $0,21 \mathrm{~mm} \times 0,21 \mathrm{~mm})$. Skany wykonano w płaszczyźnie horyzontalnej w standardzie dicom. $\mathrm{Na}$ podstawie obrazowania określono dokładność odwzorowania, która zabezpieczała odpowiednią jakość modelu numerycznego. Odwzorowanie wykonane w programie Amira 3.1 eksportowano do programu FEMAP NE/Nastran v.8.3 Modeler $\mathrm{z}$ wprowadzeniem podstawowego układu odniesienia płaszczyzn: strzałkowej, czołowej horyzontalnej. W rekonstrukcji uwzględniono struktury kostne z rozróżnieniem na kość korową i gąbczastą.

W opracowanej metodzie preferuje się wykorzystanie zależności między gęstością tkanki kostnej a jej właściwościami wytrzymałościowymi. Gęstość tkanki kostnej pacjenta ma znaczenie dla pozycjonowania i stabilizacji implantu. $U$ diagnozowanego pacjenta, $w$ konsultacji z radiologiem i ortopedą oceniono gęstość struktur kostnych w aspekcie osteoporozy. Wykluczono zmiany osteoporotyczne. Parametry jakościowe i geometryczne wyróżnionych tkanek pacjenta miały podstawowe znaczenie dla aplikacji i pozycjonowania komponenty panewkowej i komponenty udowej. Prawidłowa biomechanika zespołu kostno-stawowego kończyny dolnej jest zdeterminowana korelacją parametrów anatomicznogeometrycznych panewki oraz parametrów kości udowej. Parametry geometryczne wyznaczono w przyjętym układzie odniesienia na kompleksowym modelu numerycznym z wykorzystaniem metod geometrii wykreślnej: kładów, obrotów, przekrojów oraz podstawowych pojęć prostopadłości prostej do płaszczyzny, prostopadłości płaszczyzn, wyznaczenia kąta pomiędzy prostymi i płaszczyznami i wyznaczenia kąta między prostą a płaszczyzną.

Wybór wielkości endoprotezy powierzchniowej, bez względu na rodzaj systemu, rozpoczyna się od doboru wielkości komponenty głowowej, która uzależniona jest od parametrów geometrycznych kości udowej. Dlatego też w prezentowanej metodzie w pierwszej kolejności dokonano pomiarów głowy kości udowej. Średnice głowy wynosiły $49,9 \mathrm{~mm}$ i $47,6 \mathrm{~mm}$, a średnice szyjki były odpowiednio $34,8 \mathrm{~mm}$ i $36,5 \mathrm{~mm}$. Oś trzonu kości udowej wyznaczono jako prosta łącząca środki trzech przekrojów wykonanej w części długiej kości udowej (rys.2).

Kąt szyjkowo-trzonowy zmierzono pomiędzy wyznaczoną osią szyjki a osią trzonu kości udowej. U diagnozowanego pacjenta kąt szyjkowo-trzonowy wynosił $127^{\circ}$.

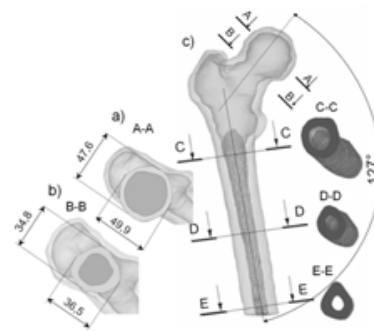

Rys.2. Pomiary kości udowej: a) średnice głowy, b) średnice szyjki, c) kąt szyjkowo-trzonowy

Optymalne warunki do zabiegu kapoplastyki powinny spełniać zakres wskaźnika głowowo szyjkowego w przedziale 1,2-1,4 [8]. W analizowanym przypadku wskaźnik ten wynosił 1,36.

Kąt antetorsji szyjki kości udowej określany jest w ten sposób, że koniec bliższy i dalszy kości udowej sa rzutowane jeden na drugi. Kąt ten wyznaczony jest przez oś szyjki i oś stawu kolanowego w rzucie na płaszczyznę horyzontalną (rys.3). Zmierzony kąt antetorsji wynosił $12^{\circ} 30^{\prime}$.

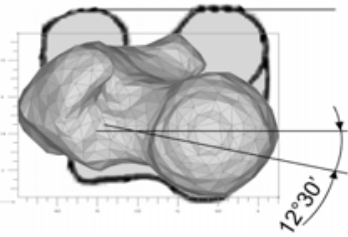

Rys.3. Wyznaczenie kąta antetorsji szyjki kości udowej

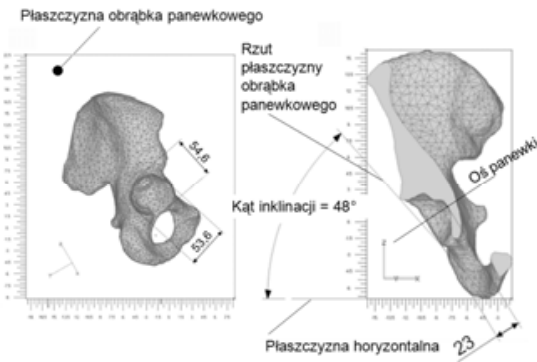

Rys.4. Pomiary panewki oraz wyznaczenie kąta inklinacji

Pomiary średnicy panewki wykonane zostały w procedurze jej kładu na płaszczyznę pochylenia utworzoną przez obrąbek kostny panewki. Przyjęto lokalny układ odniesienia $w$ ten sposób, że płaszczyzna yz jest płaszczyzną wyznaczoną przez obrąbek panewkowy a płaszczyzna xz stanowi płaszczyznę przekroju panewki przechodzącą przez jej środek (rys.4).

Panewka była owalna a jej osie symetrii wynosiły odpowiednio $54,6 \mathrm{~mm}$ i $53,6 \mathrm{~mm}$. Dla wyznaczenia głębokości panewki oraz kąta inklinacji i kąta antewersji zdefiniowano oś panewki, która jest prostą przechodzącą przez jej środek i prostopadłą do płaszczyzny obrąbka panewkowego.

Głębokość panewki wyznaczono w płaszczyźnie przekroju kości miednicznej płaszczyzną przechodzącą 
przez oś panewki i jej rzut na płaszczyznę horyzontalną (rys.4b). Głębokość panewki wynosiła $23 \mathrm{~mm}$.

Kąt inklinacji jest to kąt zawarty pomiędzy płaszczyzną obrąbka panewkowego a płaszczyzną horyzontalną. Kąt ten wyznaczono w płaszczyźnie prostopadłej do obu tych płaszczyzn jako kąt pomiędzy ich śladami (rys.4b). Kąt inklinacji wynosił $48^{\circ} 20^{\prime}$.

Kąt antewersji jest to kąt zawarty pomiędzy osią panewki a jej rzutem na płaszczyznę czołową (rys.5). Kąt antewersji mierzono w płaszczyźnie wyznaczonej przez dwie proste: oś panewki i jej rzut na płaszczyzną czołową. Wynosił on $14^{\circ} 40^{\prime}$.

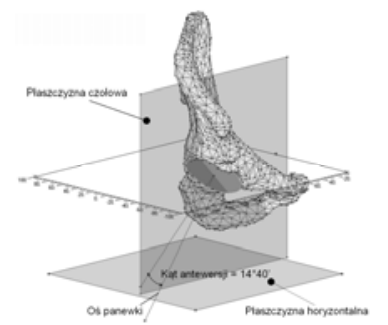

Rys.5. Wyznaczenie kąta antewersji panewki

Niepewność pomiarów liniowych wynosiła u=0,06mm, a odchylenie standardowe mierzonych kątów s=8'.

\section{Modelowanie endoprotezy powierzchniowe}

Endoprotezy powierzchniowe dopuszczone do zastosowań klinicznych produkowane są w różnych konfiguracjach materiałowych i wymiarowych, co pozwala na dobór do indywidualnych parametrów geometrycznych i biomechanicznych.

Dla realizacji pracy dokonano przeglądu rozwiązań konstrukcyjnych tego typu protez $[3,9,10]$. W prezentowanym przypadku klinicznym zastosowano endoprotezę Durom Hip Resurfacing System Firmy Zimmer (Tab.1).

Tabela 1. Wybrane informacje katalogowe DHRS

\begin{tabular}{|c|c|c|c|c|c|c|}
\hline \multicolumn{2}{|c|}{\begin{tabular}{|l}
${ }^{1}$ Protasul - \\
21 WF Alloy \\
${ }^{2}$ Protasul - \\
20 Alloy \\
cemented
\end{tabular}} & $\infty$ & \multicolumn{3}{|c|}{$\begin{array}{c}{ }^{1} \text { Porolock Surface } \\
\text { (Ti-VP5) } \\
{ }^{2} \text { Protasul }-21 \mathrm{WF} \\
\text { Alloy } \\
\text { uncemented }\end{array}$} & 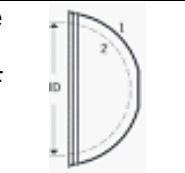 \\
\hline $\begin{array}{c}\text { Size = } \\
\mathrm{OO}[\mathrm{mm}]\end{array}$ & Code & REF & Size & $\begin{array}{c}\text { ID } \\
{[\mathrm{mm}]}\end{array}$ & Code & REF \\
\hline 38 & $\mathrm{D}$ & 01.00211 .138 & 44 & 38 & $\mathrm{D}$ & 01.00214 .144 \\
\hline 40 & $\mathrm{~F}$ & 01.00211 .140 & 46 & 40 & $\mathrm{~F}$ & 01.00214 .146 \\
\hline 42 & $\mathrm{H}$ & 01.00211 .142 & 48 & 42 & $\mathrm{H}$ & 01.00214 .148 \\
\hline 44 & $\mathrm{~J}$ & 01.00211 .144 & 50 & 44 & $\mathrm{~J}$ & 01.00214 .150 \\
\hline 46 & $\mathrm{~L}$ & 01.00211 .146 & 52 & 46 & $\mathrm{~L}$ & 01.00214 .152 \\
\hline 48 & $\mathrm{~N}$ & 01.00211 .148 & 54 & 48 & $\mathrm{~N}$ & 01.00214 .154 \\
\hline 50 & $\mathbf{P}$ & 01.00211 .150 & 56 & 50 & $\mathbf{P}$ & 01.00214 .156 \\
\hline 52 & $\mathrm{R}$ & 01.00211 .152 & 58 & 52 & $\mathrm{R}$ & 01.00214 .158 \\
\hline 54 & $\mathrm{~T}$ & 01.00211 .154 & 60 & 54 & $\mathrm{~T}$ & 01.00214 .160 \\
\hline 56 & $\mathrm{~V}$ & 01.00211 .156 & 62 & 56 & $\mathrm{~V}$ & 01.00214 .162 \\
\hline 58 & $\mathrm{X}$ & 01.00211 .158 & 64 & 58 & $x$ & 01.00214 .164 \\
\hline 60 & $Z$ & 01.00211 .160 & 66 & 60 & $Z$ & 01.00214 .166 \\
\hline
\end{tabular}

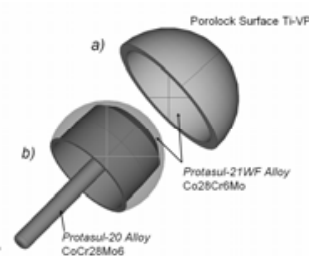

Rys.6. Elementy endoprotezy DHRS zamodelowane w programie FEMAP/NE Nastran v.8.3 Modeler: a) komponenta panewkowa , b) komponenta udowa
Do tworzenia geometrii komponenty panewkowej i udowej wykorzystano modelowanie bryłowe oparte na algebrze Boole'a [11,12] (rys.6). Z uwagi na parametry geometryczne głowy oraz panewki wybrano komponentę udową oznaczoną symbolem Durom Femoral Component 50P 01.00211.150 oraz komponente panewkowa oznaczoną symbolem Durom Acetabular Component 56P 01.00214.056.

\section{Pozycjonowanie endoprotezy powierzchniowej}

Modelowanie w programie FEMAP/NE Nastran v.8.3 Modeler daje możliwość separacji struktur, ich kładów, przekrojów i obrotów w przyjętym układzie odniesienia. Te procedury stanowią oryginalne rozwiązanie do oceny położenia, w stosunku do znanych $\mathrm{z}$ piśmiennictwa rozwiązań $[13,14]$.

Na podstawie biopomiarów pasa biodrowego pacjenta dokonano wyboru endoprotezy powierzchniowej i wirtualnego usytuowania zamodelowanych bryłowo: komponenty panewkowej w kości miednicznej i komponenty udowej na głowie kości udowej (rys.7). Komponenta panewkowa DAC 56P miała średnicę zewnętrzną $56 \mathrm{~mm}$, wewnętrzną $50 \mathrm{~mm}$, grubość ścianki $3 \mathrm{~mm}$, głębokość panewki $24,5 \mathrm{~mm}$, a punkt obrotu znajdował się w środku sfery ograniczonej kątem $165^{\circ}$. W jej usytuowaniu zachowano wyznaczony kąt inklinacji $48^{\circ} 20^{\prime}$ (rys.4.) oraz kąt antetorsji $14^{\circ} 40^{\prime}$ (rys.5.). Komponenta panewkowa na zewnętrznej powierzchni czaszy posiada porowatą warstwę tytanową i osadzana jest w kości miednicznej na zasadzie osteointegracji. W analizowanym przypadku wyznaczone kąty inklinacji i antewersji komponenty panewkowej mieściły się w strefie bezpieczeństwa wynoszącej $40^{\circ} \pm 10^{\circ}$ dla kąta inklinacji i $15^{\circ} \pm 10^{\circ}$ dla kąta antewersji zalecanych w piśmiennictwei [2,15]. Zaproponowana procedura zabezpiecza anatomiczne pozycjonowanie komponenty panewkowej w prawidłowo ukształtowanym łożu kostnym, po wyfrezowaniu jedynie resztek chrząstki stawowej i warstwy podchrzęstnej. W rokowaniach odległych zapewnia prawidłową osteointegrację, właściwy stopień przekrycia i minimalizację zużycia krawędzi panewki.

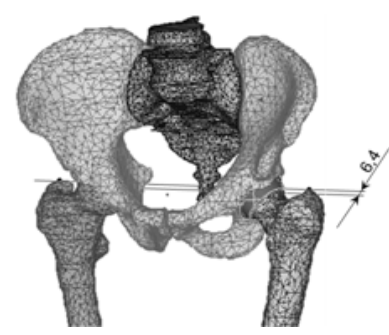

Rys.7. Numeryczny model obręczy miednicy zaopatrzony endoproteza DHRS ( DFC 50P 01.00211.150 oraz DAC 56P 01.00214.056)

Komponenta udowa DFC 50P miała średnicę zewnętrzną $50 \mathrm{~mm}$, wysokość $37 \mathrm{~mm}$, średnicę trzpienia $8 \mathrm{~mm}$ oraz jego długość 72,4 mm. W usytuowaniu komponenty udowej zachowano kąt szyjkowo-trzonowy $127^{\circ}$ (rys.2.) oraz kąt antetorsji szyjki 12³0' (rys.3.). Komponenta udowa osadzana jest na głowie kości udowej opracowanej w kształcie walca o średnicy $40 \mathrm{~mm}$ zakończonego stożkiem zgodnie $z$ procedurą zabiegową, a jej trzpień jest cementowany w opracowanym kanale szyjki (rys.8). Komponenta udowa nie wnika do kanału szpikowego, nie usuwa się szyjki kości udowej - zachowując jej anatomiczną antetorsję. Kontakt tribologiczny komponenty panewkowej i udowej realizowany jest pomiędzy warstwami ślizgowymi ze stopu Co28Cr6Mo. Optymalna orientacja elementów endoprotezy umożliwia zachowanie fizjologicznego punktu, wokół którego następuje obrót 
kończyny dolnej w płaszczyźnie strzałkowej - ruch zgięcia i wyprostu. W prawidłowym układzie biomechanicznym oś łącząca środki stawów biodrowych i prosta łącząca wierzchołki krętarzy większych powinny leżeć na tej samej wysokości. Równocześnie oś łącząca środki stawów powinna być równoległa do prostej łączącej wierzchołki krętarzy większych, leżeć w płaszczyźnie czołowej i być przesunięta do przodu o ok. $10 \mathrm{~mm}$ względem tej prostej. W badanym przypadku wyznaczono prostą łączącą wierzchołki krętarzy większych i porównano z położeniem osi łączącej środki stawów: anatomicznego i implantowanego. Prosta i oś obrotu były do siebie równoległe $z$ odchyłką równoległości $3 \mathrm{~mm}$ oraz przesunięciem osi obrotu stawów do przodu o $6,4 \mathrm{~mm}$. Usytuowanie w płaszczyźnie horyzontalnej punktów obrotu oraz przesunięcie i równoległość osi obrotu i prostej zabezpieczają funkcjonalne współdziałanie stawu anatomicznego i implantowanego.

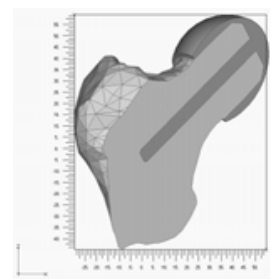

Rys.8. Osadzenie komponenty udowej DFC 50P 01.00211.150 z uwzględnieniem wyznaczonej osi szyjki kości udowej oraz kąta antetorsji

\section{Podsumowanie}

Zabieg kapoplastyki stawu biodrowego wykonywany jest z małego dostępu i operator nie może wskazać alternatywnych możliwości w wyborze i dostosowaniu endoprotez do osobniczo zmiennych parametrów anatomicznych. Standardowo przeprowadzana diagnostyka rtg również nie daje takiej możliwości.

Wspomaganie zabiegu implantacji z wykorzystaniem CT, modelowania bryłowego, biometrologii i pozycjonowania endoprotezy w wirtualnej strukturze kostnej pozwala na optymalizację doboru i takiego usytuowania, które będzie zabezpieczało parametry geometryczne w zakresie łoża kostnego i głębokości panewki, kątów inklinacji i antewersji panewki, kąta szyjkowo-trzonowego, kąta antetorsji szyjki kości udowej oraz odtwarzało oś biomechaniczną kończyny, fizjologiczny punkt obrotu w stawie implantowanym oraz położenie osi obrotu obu stawów w płaszczyźnie horyzontalnej.

Wizualizacja wyników badań może mieć różne formy. Może obejmować pełne modele, dowolnie wykonane przekroje lub struktury wyizolowane $z$ modelu przestrzennego. Wykorzystanie programów do analizy i rekonstrukcji przestrzennej obrazów tomograficznych, programów do geometrii bryłowej oraz biometrologii w warunkach implantacji endoprotez stanowi bardzo wygodne narzędzie optymalnego doboru, ponieważ w trakcie realizacji wirtualnych procedur aplikacji endoprotezy zostaje zachowany układ geometryczny struktur anatomicznych pacjenta, a zatem jest możliwość pozycjonowania implantu wobiektywnej przestrzeni operacyjnej. Można również prowadzić wirtualną separację struktur anatomicznych, rozsunięcie do aplikacji, a następnie powrót do układu oddającego rzeczywiste relacje geometryczne.

\section{LITERATURA}

[1] Marker D.R., Strimbu K., McGrath M.S., Zywiel M.G., Mont M.A., Resurfacing versus conventional total hip arthroplasty: review of comparative clinical and basic science studies, Bulletin of the NYU hospital for joint diseases, 67(2009), nr.2, 120-127

[2] Ryniewicz A., Ryniewicz A.M., Madej T., Sładek J., Gąska A., Biometrological method of pelvis measurement and anatomical positioning of endoprosthesis of hip joint, Metrology and Measurement Systems, 20(2013), nr.1, 17-26

[3] Ollivere B., Darrah C., Barker T., Nolan J., Porteous M.J., Early clinical failure of the Birmingham metal-on-metal hip resurfacing is associated with metallosis and soft-tissue necrosis, Journal of Bone \& Joint Surgery, British Volume, 91(2009), nr.8, 1025-1030

[4] Sharath K.R., Bose V.C., Birmingham mid-head resection arthroplasty of hip for avascular necrosis of femoral head-A minimum follow up of 2 years, Apollo Medicine, 9(2012), nr.4, 297-302

[5] Jiang Y., Zhang K., Die J., Shi Z., Zhao H., Wang K., A systematic review of modern metal-on-metal total hip resurfacing vs standard total hip arthroplasty in active young patients, The Journal of arthroplasty, 26(2011), nr.3, 419-426

[6] Treacy R.B.C., McBryde C.W., Shears E., Pynsent P.B., Birmingham hip resurfacing a minimum follow-up of ten years, Journal of Bone \& Joint Surgery, British Volume, 93 (2011), nr.1, 27-33

[7] Amstutz H.C., Le Duff M.J., Campbell P.A., Gruen T.A., Wisk L.E., Clinical and radiographic results of metal-on-metal hip resurfacing with a minimum ten-year follow-up, The Journal of Bone \& Joint Surgery, 92(2010), nr.16, 2663-2671

[8] Zlotorowicz M., Szczodry M., Czubak J., Ciszek B., Anatomy of the medial femoral circumflex artery with respect to the vascularity of the femoral head, Journal of Bone \& Joint Surgery, British Volume, 93(2011), nr.11, 1471-1474

[9] Van Der Bracht D., Vander Eecken S., Vyncke D., Van Dooren J., Jansegers E., Clinical and functional outcome of the Birmingham hip resurfacing, Acta Orthopædica Belgica, 77(2011), 771-776

[10] Alvarez-Vera M., Contreras-Hernandez G.R., Affatato S., Hernandez-Rodriguez M.A.L., A novel total hip resurfacing design with improved range of motion and edge-load contact stress, Materials \& Design, 55(2014), 690-698

[11] Ryniewicz A.M., Analiza mechanizmu smarowania stawu biodrowego człowieka. Uczelniane Wydawnictwa NaukowoDudaktyczne AGH, Kraków 2002

[12] Ryniewicz A.M., Identification, modelling and biotribology of human joints. AGH University of Science and Technology Press, Kraków 2011

[13] Korkmaz O., Bozkus F.S., Aykut U.S., Caki H.C., Kaygusuz M.A., The effect of component position on clinical outcomes in resurfacing hip arthroplasty, Acta orthopaedica et traumatologica turcica, 46(2012), nr.1, 13-16

[14] Coulter G., Young D.A., Dalziel R.E., Shimmin A.J., Birmingham hip resurfacing at a mean of ten years Results from an independent centre, Journal of Bone \& Joint Surgery, British Volume, 94(2012), nr.3, 315-321

[15] Sakagoshi D., Kabata T., Umemoto Y., Sakamoto J., Tomita K., A mechanical analysis of femoral resurfacing implantation for osteonecrosis of the femoral head, The Journal of arthroplasty, 25(2010), nr.8, 1282-1289

Autorzy: dr hab. inż. Anna M. Ryniewicz, prof. AGH, Akademia Górniczo-Hutnicza, Wydział Inżynierii Mechanicznej i Robotyki, Katedra Konstrukcji i Eksploatacji Maszyn, al. Mickiewicza 30, 30059 Kraków, E-mail: anna@ryniewicz.pl; dr inż. Tomasz Madej, Akademia Górniczo-Hutnicza, Wydział Inżynierii Mechanicznej $i$ Robotyki, Katedra Konstrukcji i Eksploatacji Maszyn, al. Mickiewicza 30, 30-059 Kraków, E-mail: tmadej@agh.edu.pl, dr hab. inż. Andrzej Ryniewicz, Politechnika Krakowska Wydział Mechaniczny, Laboratorium Metrologii Współrzędnościowej, al. Jana Pawła I/ 37, 31-864 Kraków, E-mail: andrzej@ryniewicz.pl, mgr inż. Łukasz Bojko, Akademia Górniczo-Hutnicza, Wydział Inżynierii Mechanicznej i Robotyki, Katedra Konstrukcji i Eksploatacji Maszyn, al. Mickiewicza 30, 30-059 Kraków, E-mail: lbojko@agh.edu.pl 